\title{
Organizational and Management Problems Confronting Redesigning Teaching and Learning in Nigerian Schools in the Globalization Era
}

\author{
Odufowokan Benard Adesina \\ Head of Department, General Studies Education \\ Tai Solarin College of Education \\ Omu-Ijebu, Ogun-State, Nigeria \\ E-mail: adesinaodufowokan@yahoo.com
}

Received: March 23, $2011 \quad$ Accepted: May 12, $2011 \quad$ doi:10.5430/jms.v2n2p78

\begin{abstract}
This study identifies the hitherto 6-5-4 educational system in relation to its sustainability vis-à-vis the recent 6-3-3-4 educational system. However, the old design of 6-5-4 and 6-3-3-4 systems have outlived their importance since the two have failed in sustaining expected socio-economic developments. Hence, the introduction of UBE and 9-3-4 education system. Subsequently, the gap created by the old designs of educational system 6-5-4 and 6-3-3-4 call for an improvement in the old design for a redesigning, reformation and re-arrangement in modes, roles, policy and planning. It is against this backdrop that this paper advocates effective and efficient redesigning and optimal implementation of the redesigned roles and objectives. The paper concludes on a note that no design of education was bad but the success or failure of any system depends solely on the implementation.
\end{abstract}

Keywords: Organizational, Management, Redesigning, Teaching, Learning, Nigerian, School, Globalization.

\section{Introduction}

The Nigerian educational system is a vast and capital intensive enterprise which operates through a combination of efficiency indicators like diverse curriculum design, Teachers, Students, Infrastructural facilities, Textbooks, Teaching resources and Financial resources. The social demand for education combined with the peculiarities of a developing nation has led to the geometric expansion in the industry over the years and statistically for over three decades, the primary level of education increased from 14,907 in 1966 to 42,600 in 1996 with a corresponding increase in pupil population from $3,025,981$ to $15,000,000(15 \mathrm{~m})$. While the secondary grammar and commercial schools increased from 717 to 6,000 during the same period. The secondary school population increased from 166,028 to $5,000,000$ (5m). This excludes the 46,906 students in the secondary modern schools. (Olagboye 2000; 14, Fafunwa 1972; 87, 1996; 67).

The National Policy on Education, 4th Edition (2004) came into existence to address the oversight of the 1977, 1981 and 1999 NPE, documents were drawn from experts representing interest groups within Nigeria. These documents were published to meet with the dynamics of social change and demands of education, policy, innovations and need to update the editions. Accordingly, the following changes and innovations were introduced;

A. (i). In pre-primary schools, there shall not be more than 20 pupils to a teacher and a helper (assistance).

(ii). In primary and secondary schools, there shall not be more than 35 and 40 pupils respectively to a class.

(iii). In technical and vocational colleges, there shall not be more than 20 pupils for practical work.

B. Primary, post-primary and tertiary education shall be the responsibility of the local, state and federal governments.

C. Education boards or similar authorities shall be responsible for the management of schools and appointments, posting and discipline of teachers within defined areas of authority.

114 , Special and adequate inducement shall be provided for teachers in rural areas to make them stay on their jobs.

Monitoring and maintenance of minimum standards

115 , Government shall establish efficient inspectorate services at federal state and local government level for monitoring and maintaining minimum standards at all levels of education below the standard level. 
116, State Ministries of Education and local education authorities in collaboration with the Federal inspectorate services, shall be the body inspecting all educational institutions under their jurisdiction.

117 , the inspectorate services shall operate as an autonomous body supervised by the

Minister of Education as may be appropriate.

\subsection{Objectives of the study}

The study sets to;

[a] Identify the organizational problems associated the hitherto 6-5-4 educational system.

[b] Highlight constraints that may hinder the sustainability of the 6-3-3-4 educational system,

[c] Point out the need for proper planning of quality efficiency indicators in the teaching and learning system.

[d] Make useful recommendations and also indicate the prospect of redesigning teaching and learning in the era of globalization.

\subsubsection{Research Questions}

To be able to achieve the objectives of the study, the following research questions are generated;

Q1. Can the local, state and federal government be responsible for funding primary, post-primary and tertiary education with the present economic melt-down?

Q2. Are there in required quantity and quality efficiency indicators like curriculum design, teaching and non-teaching personnel, infrastructural facilities, textbooks, teaching and financial resources?

Q3. Has government created enough classrooms for the expansion of enrolment of pupils and students in the schools?

Q4. Has textbooks and teaching resources been provided to meet the redesigned pattern of teaching and learning in Nigerian schools?

Q5. What other educational management problems confront the redesigned teaching and learning apart from financial resource in schools?

\subsection{Importance of the study}

To achieve the desired outcome expected from redesigning and rebranding of teaching and learning process. The old educational systems of 6-5-4 and 6-3-3-4 have to be replaced by the new Basic Education which suggests a 9-3-4. That is, 9-year of first level of education, 3-year of secondary education and 4-year of tertiary education. However, emphasis has been placed on the first 9-year with adult and non-formal education programs at the primary and junior education levels for adults and out of school youths.

To avoid any doubt, the goals of basic education have been the same as goals of the other levels of education to which it applies; i.e. primary education, junior education, adult and non-formal education. (NPE, 3; 8)

\subsubsection{Theoretical Framework}

Educational Management is emphatically concerned with the students conceptual growth and understanding. It develops in the students and understanding of concepts and issues that are fundamental to Nigeria's educational system, history, policy procedures, laws, edicts, and functions (Odufowokan 2005), though, management defies single precise definition. The entire concept and process centers on same meaning from all available definitions. Breech (1957), quoted by Olowoye, (2000) define Management as a social process entailing responsibility for the effective planning and regulation of the operations of an enterprise, such responsibility resolves an installation and maintenance of proper procedures to, ensuring adherence to plans and the guidance, integration and supervision of the personnel comprising the enterprise and carrying out of its operations while Coombs corroborated that - any productive system with whatever aims and technology requires management, leadership and direction, supervision and coordination, constant evaluation and adjustment.

Put differently, management when applied to education means the application of management principles and procedures to education industry in order to coordinate the human and material resource toward the accomplishment of educational objectives, it is a way of avoiding static social change, policy and demands of education that is characterized by the past systems of 6-5-4 and 6-3-3-4. The distinction of final productive education, unlike other industries makes education special, the end product are human beings whose behavior and character are reformed, hence, management concentrates on the effectiveness and efficiency of school operations and complete integration among various schools and school levels. 
From all indications, it is affirmed that organization and management problems are not new in human endeavor; therefore changes in design, policy and procedure cannot but be expected in educational institutions such as primary, secondary and tertiary levels in Nigeria (Odufowokan, 2007)

Retrospection a little on the past design of educational system; Four major era could be identified and these are:

(a) during the colonial Era 1942-1960.There were notable developments of emergence of initiative to provide Western education by Missionary groups, sudden expansion of the school system aided by a strong competition among voluntary agencies and private proprietors, introduction of payment by result grant scheme, dominance of education by the Missionaries, selective attendance that limits opportunity of secondary and tertiary education with the exception of few who had government and community scholarships. Also, Boards of education came on board with a view to regulate standards and supervise schools.

(b) the post-independence Era (1960-1970) witnessed the organizational and management of education that featured rising hopes and aspirations at the beginning of a period which was cut short by the Nigeria Biafra war of 1967-1970 which disrupted the educational system. Accordingly, Nwagwu (1998) asserts, steps were immediately taken towards rebuilding, restructuring and rehabilitation of the entire educational system through the 1960 Ashby report on higher education in Nigeria by sitting Advanced Teacher Training Colleges and four-year degree program for WASC holders.

The establishment of the University of Nigeria, Nsukka in October,1960, by Eastern Regional Government as a full fledge University which combined British and American Universities system of course system; elevation of Colleges of Arts and Science to University of Ife and Ahmadu Bello University followed the establishment of University of Lagos. Suffice to say, was the establishment of four pioneer Colleges of Education by UNESCO in four different zones of the Federation that is Owerri, Lagos, Ondo, and Zaria. These were named Advanced Teacher Training Colleges. By 1969, the desire, aspirations and yearning of the Nigerian populace was herald in Curriculum Conference which purported functional educational system that led to the formulation and launching of the National Policy on Education.

(c) Post Civil War Era - This period was an important period in the history of Nigerian Educational system and that of the country at large. It was busy at restoring all that was battered during the warring period. Outstanding among these were the taken over by some private and voluntary agencies, schools including state governments with no reasons (Nwagwu 1987, Fafunwa, 1974). Federal Government took over State Universities in 1975, lack of expansionary plans for education that equated pupils, plants and finance for economic growth and development (FMF, 1992), Launching of the 6-3-3-4 system in 1972 was greeted with many socio-economic problems through its compulsion of mother tongue in teaching local pupils, prevocational subjects at junior secondary school level and technical education subjects at the last three years. Of course, we had the structural Adjustment Era (1981-1990) and the instability and the uncertainty Era (1991-1998), both era witnessed moves and attempt at solving the age long Socio-economic, political problem of financing education from sale of oil and petroleum products which of course has its significant effect on education whenever there is recession, glut, or economic melt-down being experienced presently. Funds available to education had always fall short of the required hence private institutions up to University level had always sprang up to make up for the deficiency. Consequently, the need to assess education policies and programmes became imperative for whatever happened to the head has affected the entire body.

Essentially, the unfolding events in Nigerias` educational sector has not left the old design of education untouched even with the demise of the erstwhile Professor under whom the 6-3-3-4 system was introduced in 1989. Consequently, the resurgence of hit debate on education is as a result of the death of Late Professor Babatunde Fafunwa as Federal Minister of Education.

Interestingly, Reuben, (2010) in Nigerian News of 25th October, 2010 wrote it is common knowledge that the 6-3-3-4, was the first major reform in Nigeria`s education system for decades and it is generally referred to as Fafunwas' baby, although, in one notable presentation, Senator Jubril Aminu, also a former Minister of Education, argues that the policy was conceived under the Military Head of state - General Yakubu Gowon`s administration. This was the major contribution of Somade`s Commission on Education.

Indisputably, no one has ever been more vocal and more determined in raising the quality of education in Nigeria than Fafunwa.

Reuben, corroborating further on the importance of 6-3-3-4 asserts that Fafunwa had the defense of the 6-3-3-4 system as his life-long battle which he did with uncommon passion and faith. In October, 4, 2010, while speaking at an educational summit in Abuja, trying to provide an excuse for the high rate of failure in the Senior School Certificate Examination (SSCE) blamed the 6-3-3-4 system and asked those who introduced it to apologize to the nation and the late Professor not one shy away immediately issued a rebuttal, stating that he had no reason to apologize to Nigerians: 
"It is true" he said "that I proposed the 6-3-3-4 system of education in 1989. He continued "I don't have any apology about it. Our problem is not the system but failure to implement what was recommended before cancellation. I believe in that system of education and I have written a book on it. Currently, it is being run in the US, Japan and other countries in the world. So, what is wrong with our own? The Late Professor queried.

Kenneth Gbagi, in October, 14, 2010, the present Minister of state for education spoke during the same week the late Professor died at a meeting with the 36 state chairmen of the Universal Basic Education Commission (UBEC) about the Federal Governments' plan to scrap the 6-3-3-4 system and revert to the old 6-5-4 system with effect from the next academic session. Consequently, there was a snide remark about how the 6-3-3-4 was imported from the United States and that accordingly in the view of a Federal government panel on education, is the source of Nigeria's educational crisis.

\subsubsection{Analysis of Data.}

Eight hundred (800) subjects were sampled for this study to respond to questionnaires and sixty (60) highly placed educationists were also interviewed on issues related to redesigning of teaching and learning for sustainable development in an era of globalization in Nigeria schools. 500 male and 300 female constituted randomly selected respondents who answered the questionnaire drawn in responsive form of "Agree " "Not Agree" and "Undecided" was used; for example, Item 2 on the questionnaire states 'I am aware that states ministry of education are responsible for implementing directives from Federal Ministry of education'. 42 male and 18 female constituted the senior staff that were interviewed.

The population comprised of all stakeholders in the education industry drawn from three major geo-political zones in Nigeria. (Hausa - North, Ibo - Southeast and Yoruba - Southwest). Eight states were chosen from the north while six states were chosen each from southeast and southwest respectively. Out of the respondents who responded to questionnaire, 280, 260 and 260 were respectively from the zones in the order above with a wide coverage for respondents from Federal and State Ministries, Commissions, Boards and Zonal Education Personnel, Teachers and Students. Self developed instrument tagged Organizational Management Confrontational Problems in Education Questionnaire (OMCPEQ) were administered in the twenty states through the help of research assistants.

Teachers and Students were drawn forty (40) secondary schools in each state. These formed the twenty junior secondary schools only and senior secondary schools only. Respondents were told that the researcher meant to validate and justify redesigned 9-3-4 system of education and ascertain likely advantages inherent in the Universal Basic Education system thereby making the first 9 years compulsory for starters. Students were however not interfered with while answering questionnaire. Frequency counts and percentages were used to analyze the data which were collected, collated and the result used to re-affirm issues highlighted in the research question. The information collected is presented below.

\subsubsection{Discussion of findings}

Out of the 800 respondents sampled for the study, 640 representing $80 \%$ indicated that the educational industry needs to be redesigned at all levels, that is primary, secondary and tertiary and this should be done by the local, state and federal government. This is because the present design has too much over-lap functions and confusion on who is in charge of what in the education industry which has resulted in colossal wastage, lack of accountability, inadequate funding, duplication of programmes, organization and management conflicts, while 96 respondents representing $12 \%$ indicated that the problem of education goes beyond redesigning of educational system. They were of the opinion that the government through its representatives is not sincere enough to pursue different programmes it launched to logical end. For example, the seven point agenda and vision 20-20-20 of Late President Sheu Musa Yar Adua. The other 64 (8\%) were undecided.

Apart from the capital intensity of funding, the globalization era exposes the whole world as a global village where communication can connect the seven continents within minutes through computer, fax, gsm, telex. The use of plane and helicopters for transportation and many others.

Forty-two out of sixty educators interviewed agreed that government could design and implement the design to the latter. They were of the opinion that provision of education and related inputs including personnel is a social responsibility and as such, should make adequate and appropriate allocation for education in annual budget plans. If education is an instrument used to fight ignorance, restore trust and lost confidence, then the government should live up to expectation by removing ignorance completely from her people to facilitate rapid economic growth and development in the globalization era. 


\section{Stakeholders and Indicators in the Redesigning of Teaching and Learning.}

\subsection{Personnel involved in the curriculum and structural design.}

Respondents were asked to indicate who are those involved in teaching- learning design. These include Federal Ministry of Education staff, Director-General, Deputy Directors and assistant Directors of the Federal Ministry of Education, State Ministry of Education staff, States Director-General, Zonal Education Officers, Principals and Heads of Primary Schools. Table 1 shows the analysis of responses.

\section{$<$ Table 1 about here $>$}

The figures reveal that $84.5 \%, 86 \%, 88 \%, 88 \%$, and $85 \%$ of the respondents indicated that all the federal and state ministry of education staff are involved in the structural and curriculum design in teaching and learning. The highest responsibility is attached to the Federal Ministry of Education with unfavorable responses of $10 \%$, while $8 \%, 6 \%, 12 \%$ and $13 \%$ were negative answers to non-involvement of States Ministry of Education, Federal Education Commission, States Boards, Teachers, Students and Pupils in the design of teaching respectively. From all indications, it is glaring that there are enough personnel that can prosecute the redesigning program. The main actors of the redesigning programme abound in educational institutions.

\subsection{Students Enrolment Relationship to Curriculum and Structural Design.}

The sample subjects were asked to indicate, if the students and pupils annual enrolment takes into consideration the size of structural designs. For example, classrooms, lecture halls, auditoria, hostel, lavatory, library, sports field, clinic, est. available to pupils and students. Those asked were the Head teachers, Principals, Vice-chancellors, Teachers, Lecturers, Pupils, Students and Parents of pupils in the school. Their responses are showed in Table 2.

$<$ Table 2 about here $>$

The above table reflects an average percentage of awareness of the shortfall of awareness of the obsolete curriculum and structural design is 90. 9\%. The awareness of the Vice-Chancellors, Principals and Head teachers, Lecturers and Teachers, Pupils and Students cum parents has $90.0 \%, 88.5 \%, 89.0 \%$, respectively but these are below average while that of the parents is above average with $95.5 \%$.

This is due to the fact that the parents are directly affected by the inadequacy in the curriculum and structural design. The products of the system that are either employed or not go home as output. This was closely followed by those of the Vice-chancellors, Principals and Head teachers, Pupils and Students, lecturers and Teachers with 90.6\%, 89.0\% and $88.5 \%$ respectively. The awareness of pupils and students, lecturers and teachers were close to the average of $90.9 \%$.

One important revelation by the table is that of highest awareness coming from the parents. One would have expected a contrary view of students' awareness above that of the Vice-chancellor, Principal and Head teachers, and of course that of Pupils and Students since they are the input in the input-process-output system of education.

\subsection{Efficiency and Adequacy of the Present Curriculum and Structural Design}

Respondents i.e. Vice-chancellors, Principals, Head teachers, Lecturers, Teachers, Pupils, Students and Parents were asked if the present design is effective and adequate. Their responses are as in Table 3.

\section{$<$ Table 3 about here $>$}

The figures reveal that $75 \%, 84.5 \%, 69 \%$ and $90 \%$ of the respondents indicated that there were insufficient and inadequate curriculum and structural design in educational institutions in Nigeria. The highest inadequacy emanated from the parents with $90 \%$. This is because the parents are directly responsible for payment of students` school fees and other related expenses including donations in support of physical structures like library, workshops laboratories, buses to mention just a few.

This is evident in the call for individual donors, corporate bodies, financial institutions and World Assisted Program coordinating units. Recently, there is world recession caused by the persistent fall in prices of oil and petroleum allied products causing socio-economic melt-down.

\section{Organizational and Management Problems of Redesigning Teaching and Learning}

Responses from respondents reflect that past and present design has fallen short of required and expected economic growth and development hence the need for a redesign to affect a turnaround while sustaining the already inadequate level of production, employment and distributive resources. 


\subsection{Adequacy of Textbooks, Teaching and Financial Resources Have Being Taken Care Of In the Redesigning Of} Teaching and Learning

Responses from respondents reflects that there had never been an adequate planned culture which would keep the existing textbooks and other important resources as well as providing new once that would meet the actual demand of these resources. In order words, adequate planned culture is a function of available funds at a particular time. Vice-chancellors, Principals, Head teachers, Pupils and students, Lecturers and teachers, and of course, parents responded negatively to adequate planned culture of keeping existing textbooks and other resources while providing new once. Strict management of existing textbooks and making provision for new once to meet the required number has been a mirage in teaching and learning process in Nigeria.

\section{$<$ Table 4 about here $>$}

The figures above reveal that the highest percentages from the respondents are positive. $93 \%$ of the responses indicate that respondents were aware of the adequate planned culture and also $96.5 \%$ were aware of the importance of textbooks, teaching and financial resources to teaching and learning as provision of these in required quantity and time would help produce positive desired results in education which would in turn increase the growth and development of the students and pupils, schools and school personnel as well as the society at large.

One important observation from the table is that the benefits of adequate textbooks, teaching and financial resources in teaching and learning are known to every stakeholder in education. With a response of $91.5 \%$. There is no doubt, that if textbooks, teaching resources like instructional materials, video player, tape recorder, television and improved funding is made available to education in required quantity, the level of growth and development of the economy would increase to a desired and prosperous level.

Responses as mentioned earlier from those sampled for the interview greatly support the data from the questionnaire. The majority of respondents were in the knowledge of adequate textbooks, teaching and financial resources. They quite know that good and relevant textbooks, provision of teaching resources couple with adequate funding enhances teaching and sustains socio-economic development in the long run.

\section{Summary of Findings}

Despite the intimidating population, school enrolment, varied curriculum design, inadequate teaching personnel among others. The responsibility of design and redesigning teaching and learning remains with the government, hence the provision of personnel, materials, funding and of course the matching of these into the design rests on the government as well. Odufowokan (2008)

The government and other stakeholders in education though, are currently being incapacitated due to global economic melt-down caused by persistent fall in price of oil and allied products. This apart, the geometric growth in population generally, pupils and students enrolment caused by government (military/civilian) various education policies e.g. N.P.E., N.B.E. est.

The existing physical facilities can no longer serve the number of students in educational institutions because they have been stretched beyond their elasticity capacities hence the need for a redesigning. Inadequate funding has had its attendant effect on various forms of designing in education. It is hoped that the redesigning intended would take into consideration available funding to match the anticipated growth and development with education in the era of globalization.

\section{Recommendations}

From the findings of the study, the following recommendations are being made, so that Nigeria can benefit maximally from redesigning teaching and learning in Nigerian schools.

There have been cries and calls over the radio, television and the dailies that the government should not and cannot bear the burden of education alone. The assistance of the firms, corporations, individuals and worlds superpowers and their agencies like UNESCO and World Bank, would go a long way in strengthening the existing design of 6-3-3-4 as well as putting intended new design in place. It is believed that the redesign intention is to fine-tune the existing structural and curriculum designs hence; the need for financial support spreads its octopus tentacles to many areas. These include the provision of required and suitable agency and agents, personnel, teaching and financial resources, textbooks, structure and curriculum that will support and sustain the desired socio-economic growth and development.

A more functional supervision and monitoring should be introduced into the school system, emphasizing a unique way of handling the implementation of the redesigning structures and curriculum. In the words of Odufowokan (2009). It is not enough to redesign an already produced product, but the sustainability of the redesigned product to yield desired result. 
Finally, to ensure both organizational and management success, there should be a definite government paper on the redesign quality indicators and implementation of $26 \%$ of annual budget earmarked for education.

\section{Conclusion}

The actualization of any educational design depends solely on the available financial resources. As simply put by some scholars and researchers like Fafunwa (1972), Fields (1974), Akinwunmiju and Martins (1987), Olaloko (1991), Durosaro (1981, 1986), Adeboyeje (2000), Olowoye (2000) and Nwagwu (1998). Funding is a necessary condition for effective realization of redesigning objectives. The provision of necessary structures and curriculum in required quantity help the teaching-learning process for which the educational institution is built.

\section{References}

Akinwunmiju, J and Martins, A [1987), 'Basic Principles of Planning` The Paper presented at the International Workshop on Management and Planning in Nigeria, University of Ibadan, Ibadan.

Fafunwa, A.B. (1972) The Purpose of Teacher Education in Adaralegbe A (Ed) A Philosophy for Nigerian Education. Ibadan; Heinemann Educational Books (Nig) Ltd

Federal Republic of Nigeria, (1995), Ministry of Finance Report, Lagos

Fields, (1974) Personnel Administration: Point of view and Methods, New York, McGraw-Hill.

Federal Republic of Nigeria (1999). The Constitution of the Federal Republic of Nigeria.

Federal Government of Nigeria (2004) National Policy on Education. Lagos, Nigeria.

Nwagwu (1998) Historical Sketches in the Development of Educational Management in Nigeria. In Olagboye and Fadipe (Eds) Management of Nigerian Education Law, Structures and Responsibilities. NIEPA. Ondo.

Odufowokan B.A. (2005) Concepts and Issues in Educational Management. Bosun Publishers, Ijebu Ode.

Odufowokan B.A. (2007) Organization and Administrative Problems Confronting the Maintenance of School Plant in Nigerian Secondary Schools. Journal of Applied Education and Vocational Technology Vol 1, No 2. TASUED, Ijagun.

Odufowokan B.A. (2009) The Political Economy and the Challenges of Education in the $21^{\text {st }}$ century. JORGSE, Emmanuel Alayande College of Education, Oyo.

Olagboye A.A. (2000), Employment Process and Placement of Personnel for QualityEducation in Nigerian Secondary Schools. In Fadipe J.O. and Ojedele P.K. (Eds)Management of Nigerian Education; Personnel Administration and Quality in Education; NIEPA, Ondo.

Olowoye B (2001) Principles and Methods of Teaching. Lucky Odoni Publishers, Ijebu-Ode.

Nigerian News, $25^{\text {th }}$ October, 2010. Reforming Nigeria's` Educational System, 6-3-3-4 or 6-5-4?

UNESCO, (1968) 'Educational Planning: A Survey of Problems and Prospects' Working Paper International Conference on Educational Planning, Paris: 111P.

World Bank, (1990) Comparative African Experience in Implementing Educational Policy, Discussion Papers, Africa Technical Department Series, No 83, Washington. 
Table 1. Functionality of Personnel involved in the design of teaching-learning in Nigerian schools.

\begin{tabular}{|c|c|c|c|c|c|c|}
\hline & Yes & $\%$ & No & $\%$ & U & $\%$ \\
\hline $\begin{array}{c}\text { Federal Ministry of Education Play } \\
\text { Significant Role in the Design of } \\
\text { Teaching and Learning }\end{array}$ & 704 & 88 & 80 & 10 & 16 & 2 \\
\hline $\begin{array}{c}\text { States Ministry of Education Directly } \\
\text { Implement the Design As Directed By } \\
\text { Federal Ministry of Education }\end{array}$ & 688 & 86 & 64 & 8 & 48 & 6 \\
\hline $\begin{array}{c}\text { Federal Education Commissions, State } \\
\text { Boards and Zonal Education Staff Are } \\
\text { Involved in Design and Implementation }\end{array}$ & 704 & 88 & 48 & 6 & 48 & 6 \\
\hline $\begin{array}{c}\text { Teachers Role Is Important In } \\
\text { Implementation }\end{array}$ & 676 & 84.5 & 96 & 12 & 28 & 3.5 \\
\hline $\begin{array}{c}\text { Students and Pupils Are Fully Focused } \\
\text { During Structural and Curriculum } \\
\text { Design }\end{array}$ & 680 & 85 & 104 & 13 & 16 & 2 \\
\hline
\end{tabular}

Table 2. Students Enrolment Rate Relationship to Curriculum and Structural Design

\begin{tabular}{|c|c|c|c|c|c|c|}
\hline & Yes & $\%$ & No & $\%$ & U & $\%$ \\
\hline $\begin{array}{c}\text { Vice-Chancellors, Principals and Head teachers } \\
\text { Know That the Available Structural Design Is } \\
\text { Over Stretched and Obsolete }\end{array}$ & 720 & 90.0 & 52 & 6.5 & 28 & 3.5 \\
\hline $\begin{array}{c}\text { Lecturers and Teachers Are Aware That } \\
\text { Enrolment Rate Has Outgrown the Existing } \\
\text { Structural Designs }\end{array}$ & 708 & 88.5 & 68 & 8.5 & 24 & 3.0 \\
\hline $\begin{array}{c}\text { Pupils and Students are aware of the vacuum } \\
\text { In the Curriculum and Structural Design }\end{array}$ & 712 & 89.0 & 72 & 9.0 & 16 & 2.0 \\
\hline $\begin{array}{c}\text { Parents Know and Are Conscious Of The } \\
\text { Inadequacy of Curriculum and Structural } \\
\text { Design }\end{array}$ & 764 & 95.5 & 20 & 2.5 & 16 & 2.0 \\
\hline Average & - & 90.9 & - & 6.64 & - & 2.68 \\
\hline
\end{tabular}

Table 3. Adequacy of the Present Curriculum and Structural Design

\begin{tabular}{|c|c|c|c|c|c|c|}
\hline & Yes & $\%$ & No & $\%$ & U & $\%$ \\
\hline Vice-chancellors, Principals and Head teachers view & 600 & 75.0 & 96 & 12 & 104 & 13 \\
\hline Lecturers and Teachers view & 676 & 84.5 & 48 & 6 & 76 & 9.5 \\
\hline Pupils and Students view & 552 & 69.0 & 40 & 5 & 208 & 26 \\
\hline Parents view & 720 & 90.0 & 32 & 4 & 48 & 6.0 \\
\hline
\end{tabular}


Table 4. Adequacy of Textbooks, Teaching and Financial Resources in Teaching and Learning.

\begin{tabular}{|c|c|c|c|c|c|c|}
\hline & Yes & $\%$ & No & $\%$ & U & $\%$ \\
\hline $\begin{array}{c}\text { Do you know of adequate planned culture } \\
\text { Of textbooks, Teaching and Financial } \\
\text { Resources? }\end{array}$ & 744 & 93.0 & 36 & 4.5 & 20 & 2.5 \\
\hline $\begin{array}{c}\text { Are you aware of the volume of existing } \\
\text { Textbooks and level of available teaching } \\
\text { And financial resources? }\end{array}$ & 680 & 85.0 & 76 & 9.5 & 44 & 5.5 \\
\hline $\begin{array}{c}\text { You are aware of the importance of } \\
\text { Textbooks, teaching and financial resources? }\end{array}$ & 772 & 96.5 & 16 & 2.0 & 12 & 1.5 \\
\hline $\begin{array}{c}\text { Do you know the benefits of having } \\
\text { Adequate textbooks, Teaching and } \\
\text { Financial resources? }\end{array}$ & 732 & 91.5 & 32 & 4.0 & 36 & 4.5 \\
\hline $\begin{array}{c}\text { I am informed about adequate textbooks, } \\
\text { Teaching and financial resources. }\end{array}$ & 572 & 71.5 & 176 & 22.0 & 52 & 6.5 \\
\hline
\end{tabular}

